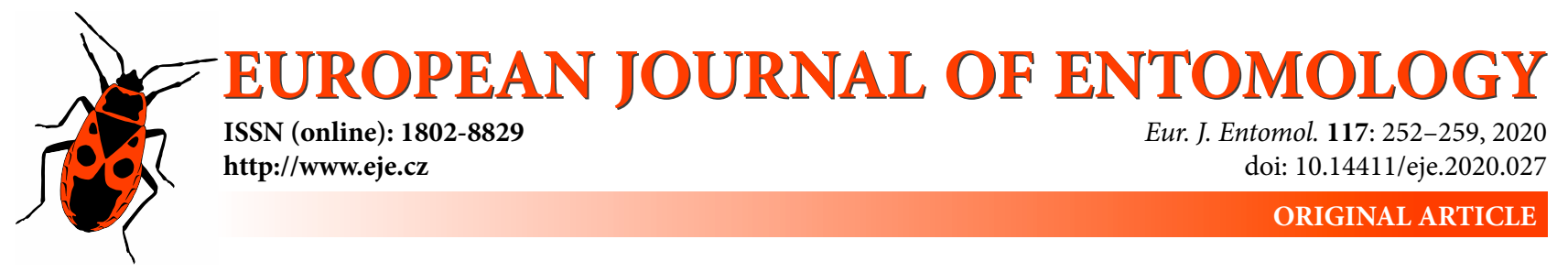

\title{
Chenicoris dilatatus, a remarkable new genus and new species of assassin bug (Hemiptera: Heteroptera: Reduviidae: Harpactorinae) from southern China
}

\author{
Zhuo CHEN ${ }^{1}$, JIANYUN WANG ${ }^{2}$, Hu LI ${ }^{1}$ and WANZHI CAI ${ }^{1, *}$ \\ ${ }^{1}$ Department of Entomology and MOA Key Lab of Pest Monitoring and Green Management, College of Plant Protection, China \\ Agricultural University, Beijing 100193, China; e-mails: insectchen625@126.com, tigerleecau@hotmail.com, caiwz@cau.edu.cn \\ ${ }^{2}$ Environment and Plant Protection Institute, Chinese Academy of Tropical Agricultural Sciences, Haikou 571101, China; \\ e-mail: wjycau@gmail.com
}

Key words. Hemiptera, Heteroptera, Reduviidae, Harpactorinae, Chenicoris dilatatus, new genus, new species, taxonomy, China

\begin{abstract}
Chenicoris dilatatus gen. n. \& sp. n. from southern China is described and placed in the largest assassin bug subfamily Harpactorinae (Hemiptera: Heteroptera: Reduviidae). The new species is similar to members of Isyndus Stål, 1859 in general habitus, but can be distinguished from the latter by the unarmed anterior pronotal lobe, the laterally dilated lobe-like abdominal segment $\mathrm{V}$ and several features of its genitalia.
\end{abstract}

ZooBank Article Registration: http://zoobank.org/urn:Isid:zoobank.org:pub:2EAA9295-CC8D-4322-91DF-74101D4C76F1

\section{INTRODUCTION}

Comprising more than 2,800 extant species in nearly 320 genera, the Harpactorinae is the largest subfamily of Reduviidae, or assassin bugs (Weirauch et al., 2014). Members of Harpactorinae are highly diversified in morphology and biology and sometimes exhibit special behaviour, such as paternal care (e.g., Tallamy et al., 2004; Forero \& Weirauch, 2017), the utilization of exogenous or endogenous sticky substances in predation (e.g., Weirauch, 2006; Forero et al., 2011; Zhang \& Weirauch, 2013; Zhang et al., 2016; Forero \& Weirauch, 2017) and bee or wasp mimicry (e.g., Zhang \& Weirauch, 2014; Gil-Santana, 2015; Alvarez et al., 2019). Members of Harpactorinae are cosmopolitan, with the highest diversity in tropical and subtropical regions. Most harpactorines are diurnal and generally found on vegetation, but some species live on the ground or tree trunks, under loose bark or stones and even inside termite nests (Miller, 1971; Schuh \& Slater, 1995). The predatory nature of some harpactorine has led them to be employed in the control of various agricultural and forest pests (e.g., Ambrose, 2000, 2002; Grundy, 2007).

First recognized by Amyot \& Audinet-Serville (1843) as "Harpactorides", Harpactorinae have long been treated as a distinct group within Reduviidae. The classification of Harpactorinae has undergone many modifications over the last 177 years and Forero (2011) summarizes the various classification schemes. Nevertheless, many systematic relationships within Harpactorinae remain unresolved, owing in part to the great number of species in this subfamily. The most recent molecular phylogeny of Reduviidae, particularly the Harpactorinae and Bactrodinae, indicates that the Harpactorinae is paraphyletic with respect to Bactrodinae, with the largest tribal-level group, Harpactorini, being polyphyletic (Zhang et al., 2016).

The Chinese harpactorine fauna has been intensively investigated since the 1940s and approximately 170 species belonging to 52 genera in four tribes have been recorded so far (e.g., Wu, 1935; China, 1940; Hoffmann, 1944; Hsiao, 1979a, b; Hsiao \& Ren 1981; Maldonado Capriles, 1990; Cai, 1995; Putshkov \& Putshkov, 1996; Hua, 2000; Cai \& Tomokuni, 2003; Zhao et al., 2006, 2007, 2009, 2014, 2015). However, due to the complexity of the physical geography of China and the great diversity of harpactorine species, actual biodiversity of Chinese Harpactorinae is still poorly understood and future field expeditions (especially to biodiversity hotspots in southern China) might lead to new discoveries. In the present paper, a unique harpactorine species from southern China is described as

\footnotetext{
* Corresponding author; e-mail: caiwz@cau.edu.cn
} 
new. As it cannot be placed into any other known genus, we establish a new genus to accommodate this species and discuss potential relationship with species of Isyndus Stål, 1859 .

\section{MATERIAL AND METHODS}

This study is mainly based on specimens preserved in the Entomological Museum of China Agricultural University, Beijing, China (CAU). The undescribed generic and species status was confirmed mainly by referring to Distant (1903-1904), Miller (1941) and Hsiao \& Ren (1981). For comparative studies we also examined the Reduviidae collection deposited in the Natural History Museum, London, U.K. (BMNH) and browsed the online checklist of Heteroptera collection in the Swedish Museum of Natural History, Stockholm, Sweden (Gustafsson, 2006).

Male genitalia were soaked in hot $10 \% \mathrm{KOH}$ solution for approximately five minutes to remove soft tissue, rinsed in distilled water and dissected under a Motic binocular dissecting microscope. Dissected genitalia were placed in a vial with glycerine and pinned under the corresponding specimen after examination. Photographs were all taken using a Canon 7D Mark II digital camera with Canon micro lens EF $100 \mathrm{~mm}$ and MP-E $65 \mathrm{~mm}$ for habitus and an Olympus BX51 microscope for dissected body parts. Helicon Focus version 5.3 was used for image stacking. The distribution map was modified from a map downloaded from the online version of SimpleMapper (Shorthouse, 2010). Measurements were obtained using a calibrated micrometer. Morphological terminology mainly follows Davis (1969) and Weirauch (2008a). The visible labial segments are numbered II to IV, given that the first segment is lost or fused into the head capsule in most Reduviidae (Weirauch, 2008b; Schuh et al., 2009).

\section{TAXONOMY}

\section{Genus Chenicoris Chen \& Cai, gen. $\mathbf{n}$.}

(Figs 1-30)

ZooBank taxon LSID:

0298BD8D-E097-4B9B-A976-B981A2E25DE2

Type species. Chenicoris dilatatus Chen \& Cai, sp. n.

Diagnosis. This genus can be separated from most other Asian harpactorine genera by a combination of the following characters: head distinctly shorter than pronotum and 1.5 times as long as width across eyes; labial segment II as long as segments III and IV combined; abdominal segment $\mathrm{V}$ laterally expanded and lobate in both sexes. The new genus is morphologically similar to Isyndus Stål, 1859, but it can be distinguished from the latter by: antenniferous tubercle without spine or denticle behind; anterior pronotal lobe unarmed laterally (in Isyndus, antenniferous tubercle with a small spine or denticle behind; anterior pronotal lobe with a pair of lateral tubercles).

\section{Description}

Macropterous male (Figs 1-3). Vestiture. Body densely clothed with erect, long, blackish pubescence and decumbent, short, golden pubescence; scape, basal half of pedicel, legs with sparse, erect, long setae and dense, suberect, short setae; apical half of pedicel, flagellomeres with decumbent, short pubescence; anterolateral angles of prosternum and apex of abdomen with dense, long, blackish setae; corium and clavus with decumbent, thick, golden setae; ventral surfaces of trochanters, femora, tibiae and tarsomeres II and III densely covered with erect, short, dark brown setae; hind tibia (except base and apex) densely covered with erect, long, greyish white setae; lateral margins of abdomen with short, delicate, blackish setae.

Structure. Body broad oval. Head (Fig. 7) wide and short, distinctly shorter than pronotum, 1.5 times as long as width across eyes; anteocular part longer than postocular (Fig. 8). Eyes globose, distinctly protruding laterally, not reaching vertex and remote from ventral surface of head in lateral view; ocelli widely separated, interocellar space slightly broader than diameter of a single eye. Antenniferous tubercle flat, without spine or denticle. Antennal scape and pedicel cylindriform, flagellomeres filiform; scape longest, subequal to combined length of head and pronotum; pedicel shorter than basiflagellomere; distiflagellomere shortest. Clypeus slightly elevated. Labium (Figs 8-9) robust, gradually curved; labial segment II subequal to the combined length of segments III and IV, exceeding middle part of eye in lateral view.

Length of pronotum shorter than its width (Fig. 7). Anterior margin slightly concave; anterior pronotal lobe short, slightly longer than half length of posterior lobe, medial longitudinal sulcus deep at base. Posterior lobe discally flat, with a pair of faint submedian carinae; humeral angles distinctly expanded laterally; posterior lateral margins eave-form, posterior angles rounded and protruding posteriorly, posterior margin nearly straight. Prosternum (Fig. 8) short, apex reaching middle of fore coxae. Scutellum (Fig. 7) triangular, wider than its length, middle of basal half flat, rounded apically. Mesopleural plica absent.

Hemelytron (Fig. 14) significantly surpassing apex of abdomen; cubital cell big, obliquely squared; base of apical internal cell in membrane more than two times as wide as that of apical external cell.

Fore coxa (Fig. 8) swollen, nearly contiguous in ventral view; femora (Figs 1-3) thickened, the fore pair more than others; subapical portion of each femur slightly sinuate; tibiae (Figs 11-13) longer than their respective femora, slightly swollen at apex, fore and mid tibiae slightly curved at apex; tarsi (Figs 11-13) three segmented, tarsomere I very small, about one-fourth as long as tarsomere III, tarsomere III subequal to combined length of tarsomeres I and II; claws paired, a lamelliform process on basal half of each claw.

Abdomen vaguely rhombic (Fig. 14), apical 2/3 of abdominal segment IV expanded laterally, middle part of segment $\mathrm{V}$ widest, middle of segment VI narrower, forming an apparent expansion of lateral part of abdomen.

Macropterous female (Figs 4-6). Similar to male in body colour and shape, but larger in size. Posterior pronotal lobe two times as long as anterior lobe. Degree of expansion of pronotum and connexivum weaker than that in male (Figs 4, 6, 10, 15). Hemelytron only slightly exceeding apex of abdomen (Fig. 15).

Etymology. The genus is named after the Chinese entomologist Chang-Chin Chen for his kind support for this study of Reduviidae. The Greek noun coris means "bug”. Gender masculine. 

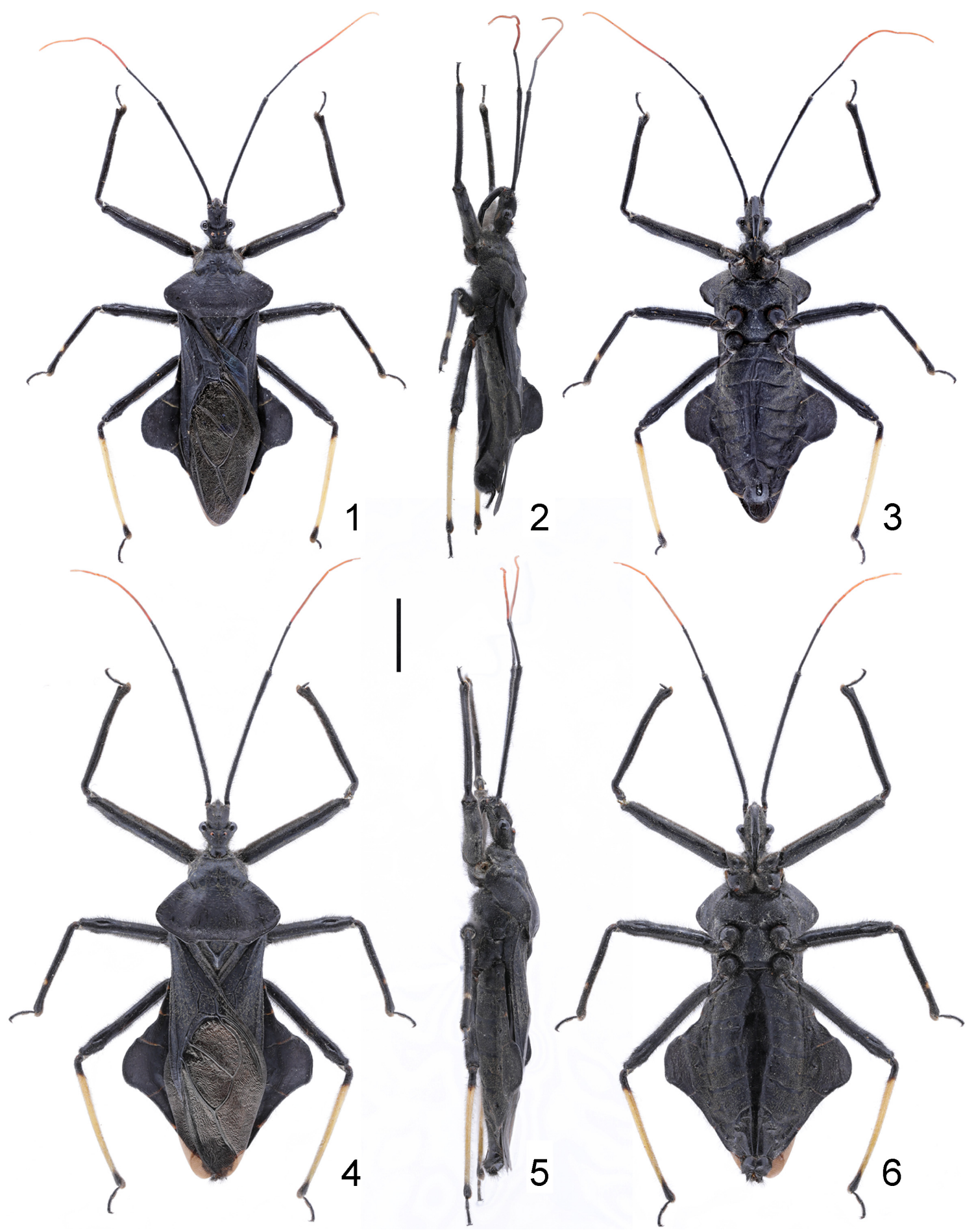

Figs 1-6. Chenicoris dilatatus Chen \& Cai, sp. n., habitus. 1-3- ${ }^{2}$, holotype; 4-6 - + , paratype; 1, 4- dorsal view; 2, 5- lateral view; 3 , 6 - ventral view. Scale bar: $5 \mathrm{~mm}$.

Distribution. China (Guangxi).

\section{Chenicoris dilatatus Chen \& Cai, sp. n.}

(Figs 1-30)

ZooBank taxon LSID:

DDC4F0F6-A8F5-4CBD-9B21-C0A9B0A1B642

Diagnosis. As for the genus by monotypy.

\section{Description (macropterous male and female)}

Coloration. Body generally black; head with a medial, longitudinal, yellowish brown line between ocelli (Figs 7, 10); ventral surface of head with an orange patch on both sides (Fig. 8); antennal flagellomeres brown; membrane glossy; mid tibia with a yellow patch subapically (Fig. 12); hind tibia yellow except base and apex (Fig. 13); posterior margin of each abdominal segment with faint orange edge. 

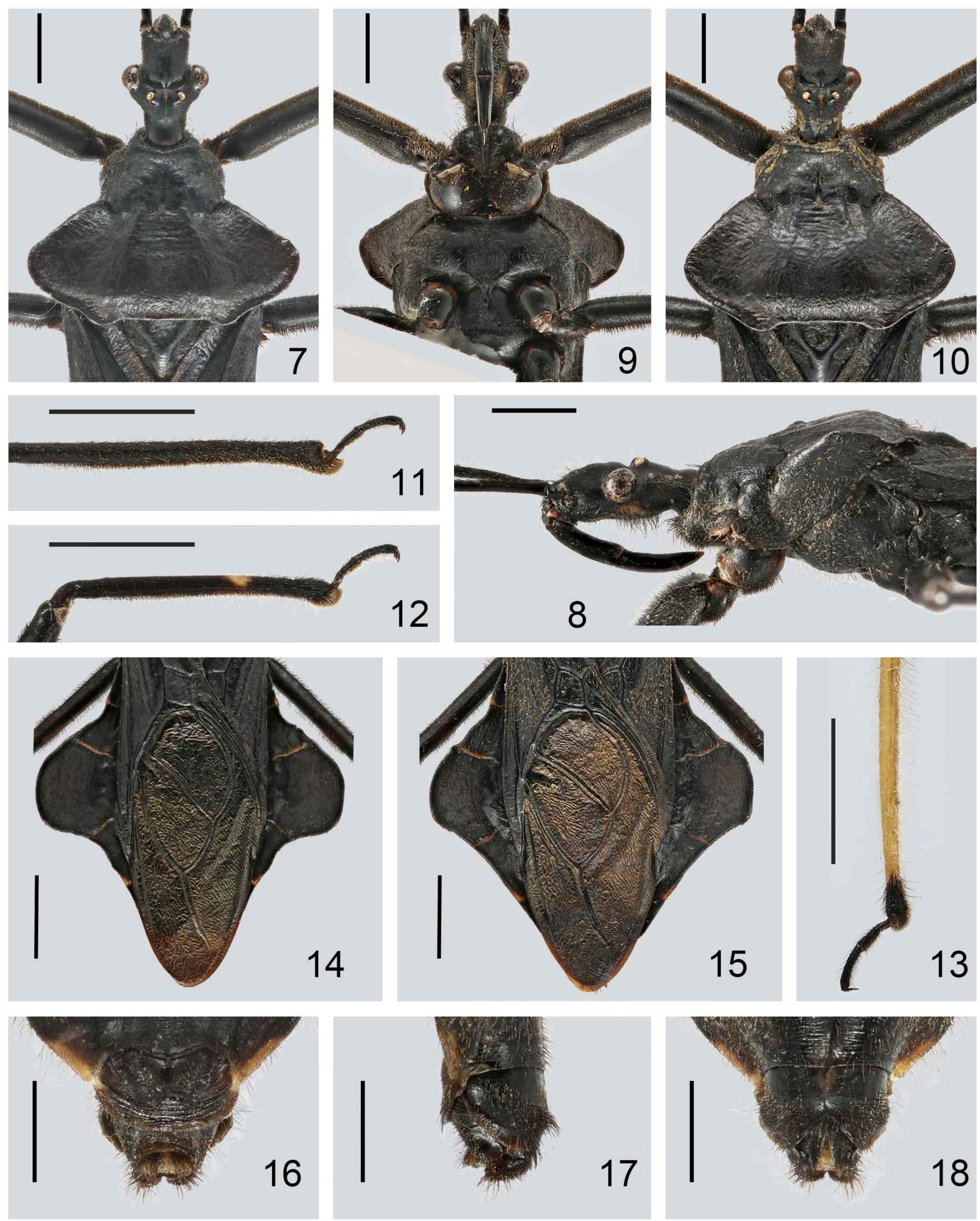

Figs 7-18. Chenicoris dilatatus Chen \& Cai, sp. n. 7-9, 11-14- 3 , holotype; 10, 15-18 - + , paratype. 7-10 - anterior part of body, with antennae and legs removed; 11 - fore tibia and tarsus; 12 - mid tibia and tarsus; 13 - hind tibia and tarsus; 14-15 - posterior part of body, with legs removed; 16-18 - apex of female abdomen. 7, 10-16 - dorsal view; 8, 17 - lateral view; 9, 18 - ventral view. Scale bars: 7-10, 16-18: $2 \mathrm{~mm}$; 11-15: $3 \mathrm{~mm}$.

Structure. Head with anteocular part $1.5\left({ }^{\Uparrow}\right)$ or $1.6(+)$ times as long as postocular; interocular space more than two times as broad as diameter of a single eye; scape twice as long as basiflagellomere, pedicel 1.2 times as long as distiflagellomere. Width of pronotum $1.6\left({ }^{3}\right)$ or $1.5($ ( $)$ times as broad as its length, collar visible; anterior pronotal 

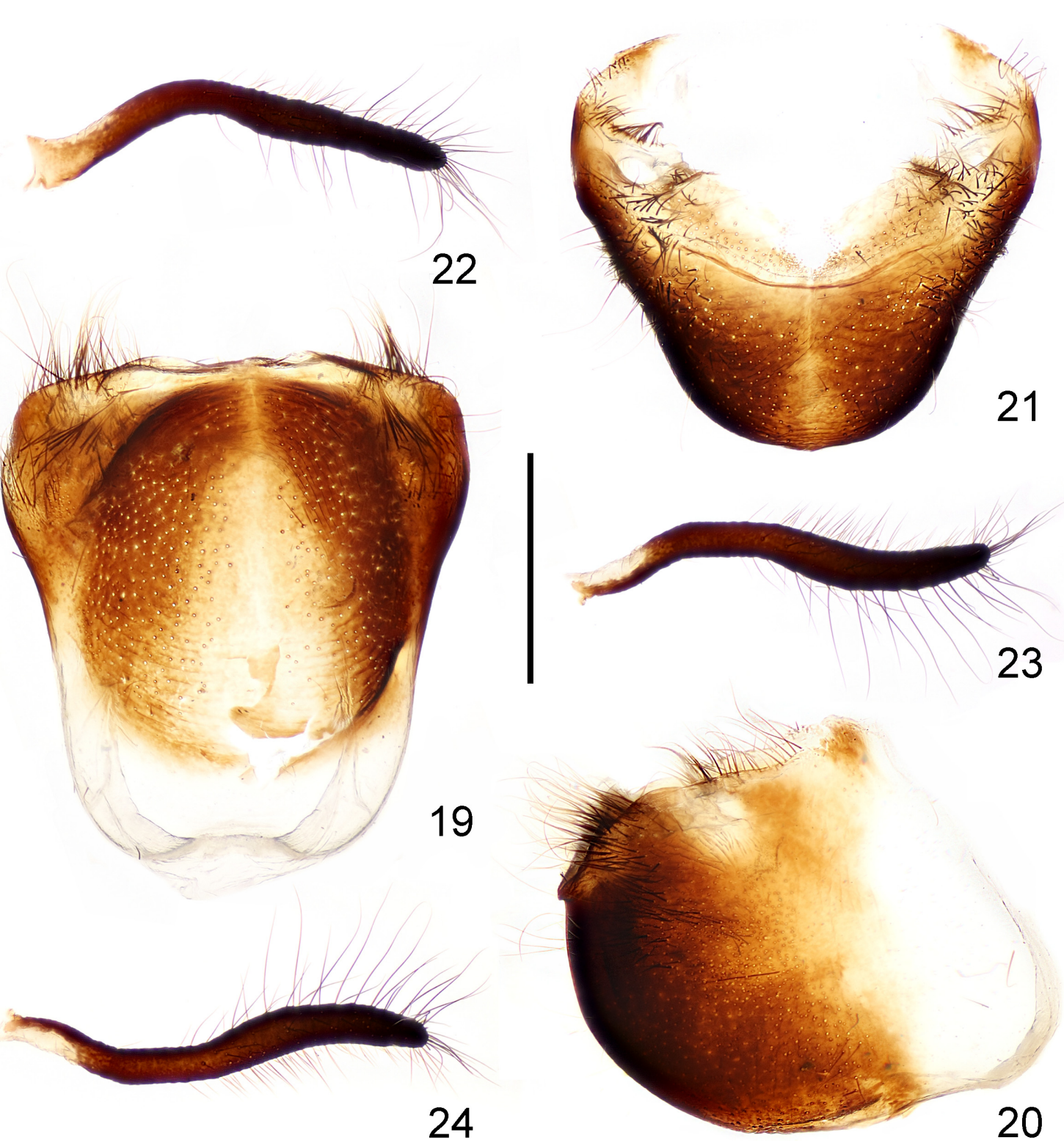

Figs 19-24. Chenicoris dilatatus Chen \& Cai, sp. n., $\widehat{~}$, holotype, genitalia. 19-21-pygophore; 22-24-paramere, three different aspects. 19 - dorsal view; 20 - lateral view; 21 - caudal view. Scale bar: $1 \mathrm{~mm}$.

lobe flat, slightly wrinkled; posterior lobe $1.7($ ふ) or two (ㅇ) times as long as anterior lobe; scutellum with a broad, Y-shaped ridge. Fore tibia slightly longer than fore femur. Length of abdomen 1.1 times as broad as its width; lateral expansion of abdomen distinctly warped up.

Male genitalia. Pygophore (Figs 19-21) oblong; posterior margin of pygophore nearly straight, median process absent. Parameres (Figs 22-24) slightly clavate, bent near base, rounded at apex, with several long setae on apical 2/3. Phallus (Figs 25-30) with articulatory apparatus thin; basal plates long and narrow, distinctly bent in lateral view (Figs 27, 28); basal plate bridge much thinner, delicately arcuate (Figs 25, 26); pedicel wide and short (Fig. 30); dorsal phallothecal sclerite broad and apically weakly concave (Figs 25, 26); struts stout, fused at middle, separated at base and apex (Fig. 25); endosoma with a pair of flat sclerites at apex (Figs 25, 27, 29).
Female genitalia. Eighth abdominal tergite dorsal and horizontal, not expanded posteriorly (Fig. 16); first valvifer broad, obtuse at apex (Figs 17, 18); first valvula triangular, covered with dense setae, sharp at apex (Fig. 18); styloids covered with dense setae apically (Figs 16-18); ninth and tenth tergites merged, visible in dorsal view (Fig. 16).

Measurements [in mm, $\hat{\partial}(\mathrm{n}=1) / q(\mathrm{n}=2)]$. Length of body: to apex of hemelytra $21.86 / 23.01-25.90$; to apex of abdomen 20.46 / 22.13-24.90; length of head 3.15 / 3.25-3.40; length of anteocular part 1.50 / 1.55-1.65; length of postocular part 0.99 / 0.95-1.10; width across eyes $2.40 / 2.36-2.60$; interocular space $1.41 / 1.25-1.40$; interocellar space $0.59 / 0.65$; length of antennal segments I-IV $=7.66 / 8.52-9.00,2.88 / 2.89-3.20,4.07 / 3.84$ $5.10,2.36 / 2.25-2.36$; length of labial segments II-IV $=1.86$ / $1.84-2.15,1.15 / 1.27-1.50,0.63 / 0.51-0.70$; length of anterior pronotal lobe 1.65 / 1.64-2.35; length of posterior pronotal lobe 2.87 / 3.29-3.75; width of anterior pronotal lobe 3.21 / 3.42-3.90; width of posterior pronotal lobe 7.34 / 7.60-8.55; median length 


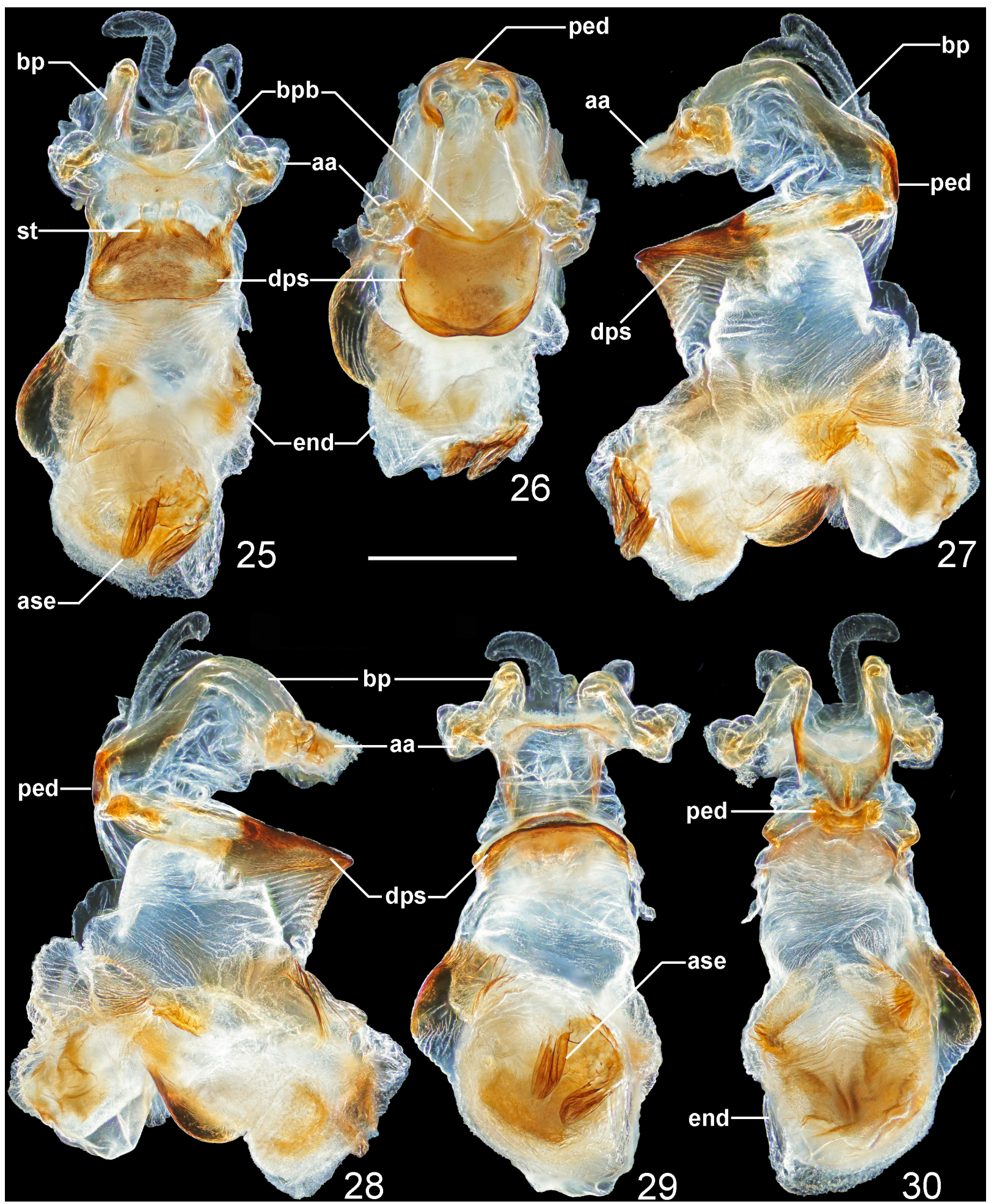

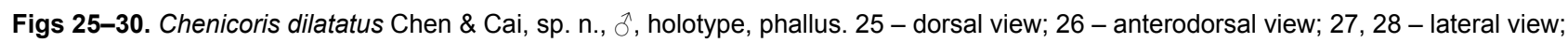
29 - caudal view; 30 - ventral view. Abbreviations: aa - articulatory apparatus; ase - apical sclerites of endosoma; bp - basal plates; bpb - basal plate bridge; dps - dorsal phallothecal sclerite; end - endosoma; ped - pedicel; st - struts. Scale bar: $1 \mathrm{~mm}$.

of scutellum 1.59 / 1.72-1.95; basal width of scutellum 2.32 2.35-2.50; length of hemelytron 14.34 / 15.05-17.25; length of fore femur, tibia, tarsus $=6.87 / 7.26-8.00,7.06 / 7.41-8.25,1.65$ / 1.63-1.75; length of mid femur, tibia, tarsus $=5.16 / 5.82-6.00$ 5.75 / 6.28-6.75, $1.52 / 1.63-1.70$; length of hind femur, tibia, tarsus $=6.66 / 7.30-8.10,8.35 / 8.60-9.25,1.80 / 1.77-1.80$; length of abdomen $10.78 / 12.05-13.50$; greatest width of abdomen 10.14 / 11.57-12.10.
Type material. Holotype: $\widehat{\jmath}$, CHINA, Guangxi, Jinxiu, Mt. Dayaoshan, Luoyingou, alt. 1200 m, 7.v.2016, leg. Jinteng Zhao (CAU). Paratypes: 1\%, CHINA, Guangxi, Jinxiu, Mt. Dayaoshan, Fenzhantun, $24^{\circ} 07^{\prime} 14.96^{\prime \prime} \mathrm{N}, 110^{\circ} 12^{\prime} 33.90^{\prime \prime} \mathrm{E}$, alt. $950 \mathrm{~m}$, 1.vi.2017, leg. J.T. Zhao (CAU). 1 , , CHINA, Guangxi, Jinxiu, Mt. Dayaoshan, Laoshanlinchang, $24^{\circ} 07^{\prime} 54.97^{\prime \prime} \mathrm{N}, 110^{\circ} 13^{\prime} 42.95^{\prime \prime} \mathrm{E}$, alt. $1200 \mathrm{~m}$, 9.vii.2018, leg. Jinteng Zhao (CAU).

Type locality. China, Guangxi, Jinxiu, Mt. Dayaoshan. 


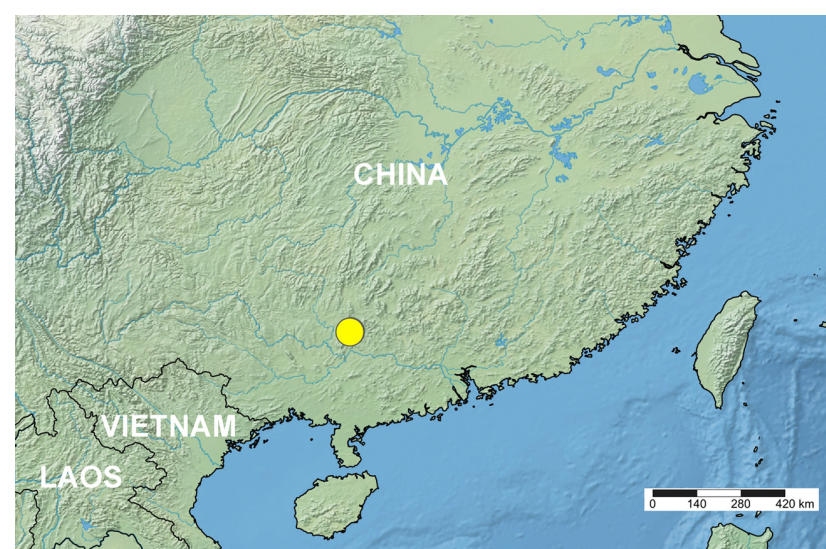

Fig. 31. Type locality of Chenicoris dilatatus Chen \& Cai, sp. n.

Etymology. The specific epithet refers to the strongly expanded abdominal connexivum of the new species, dilatatus in Latin means "dilated, expanded".

Distribution. Known only from the type locality (Mt. Dayaoshan, Guangxi, southern China) (Fig. 31).

Biology. Nothing is known of the natural history of this new species. The male specimen (holotype) was collected using a sweep net. According to the data on the label, the specimens were caught between 950 and 1,200 m above sea level.

\section{DISCUSSION}

Although many authors have studied the taxonomy of Harpactorinae, the tribal-level classification of this group still requires further work (e.g., Forero, 2011; Zhang et al., 2016). Chenicoris gen. n. has the following characters: ocelli dorsal and not as widely separated as eyes (excludes Ectinoderini); labium curved (excludes "rhaphidosomatines" and "tegeines") and clypeus lacking a long porrect median process between the antennae (excludes Dicrotelini). Therefore, Chenicoris gen. n. is placed in the tribe Harpactorini.

Chenicoris gen. n. seems to be closely related to Isyndus Stål, 1859. These two genera are similar in a number of characters, such as general body shape, hairy body surface, structure of labium, broad pronotum and thick legs. Some species of Isyndus, namely Isyndus lativentris Distant; 1919, Isyndus obscurus (Dallas, 1850) and Isyndus planicollis Lindberg, 1934, have moderately to strongly expanded posterior pronotal lobe with their humeral angles round or slightly angular, which bears a resemblance to Chenicoris dilatatus sp. n. Some members of Isyndus (such as I. lativentris, I. obscurus and I. pilosipes Reuter, 1881) also have a distinctly expanded abdomen, .

Chenicoris gen. n., nevertheless, can be clearly distinguished from Isyndus by a combination of the following characters: antenniferous tubercle without spine and denticle behind (vs. with a small spine or denticle in Isyndus); anterior pronotal lobe unarmed laterally (vs. with a pair of lateral tubercles in Isyndus); abdominal segment V strongly dilated and lobate laterally (abdomen gradually expanded, not suddenly dilated at segment $\mathrm{V}$ in Isyndus). In addition, the expansion of the abdomen in Isyndus is more obvious in females, with the male abdomens only slightly expanded, which is different from Chenicoris gen. $n$. in which the abdomen is strongly expanded in both sexes.

The male genitalia of members of Isyndus are described and illustrated by Cai \& Wang (1998). Furthermore, I. obscurus and I. planicollis were dissected for comparison in the present study. Several characters of the genitalia can be used to separate Chenicoris dilatatus sp. $\mathrm{n}$. from species of Isyndus: median process of pygophore absent (vs. median process small but distinct in Isyndus); dorsal phallothecal sclerite without tubercle dorsally and apical margin slightly concave (vs. with a pair of oval tubercles dorsally and apical margin somewhat convex at midpoint in Isyndus); struts fused at middle (vs. widely separated in Isyndus); endosoma without sclerotized process (with a pair of long, spine-like, sclerotized processes in Isyndus).

ACKNOWLEDGEMENTS. We sincerely thank P. Švácha (Institute of Entomology, Czech Academy of Sciences, České Budějovice), D.R. Swanson (University of Illinois at UrbanaChampaign, Urbana) and two anonymous reviewers for helpful comments and critical reading of the manuscript. We are grateful to V.A. Lemaitre and M.D. Webb (The Natural History Museum, London) for their kind help with the examination of Reduviidae specimens. We are also thankful to Ping Zhao (Guangdong Institute of Applied Biological Resources, Guangzhou) for her helpful discussion during this study. This work was supported by a grant from the National Natural Science Foundation of China (No. 31730086).

\section{REFERENCES}

Alvarez L.J., Zamudio F. \& Melo M.C. 2019: Eating with the enemy? Mimic complex between a stingless bee and assassin bugs. - Pap. Avulsos Zool. 59: e20195927, 6 pp.

Ambrose D.P. 2000: Chapter 29. Assassin bugs (Reduviidae excluding Triatominae). In Schaefer C.W. \& Panizi A.R. (eds): Heteroptera of Economic Importance. CRC Press, Boca Raton, FL, pp. 695-712.

Ambrose D.P. 2002: Assassin bugs (Heteroptera: Reduviidae) in integrated pest management programmes: success and strategies. In Ignacimuthu S. \& Sen A. (eds): Strategies in Integrated Pest Management. Phoenix, New Delhi, pp. 73-85.

Amyot C.J.-B. \& Audinet-Serville J.-G. 1843: Histoire Naturelle des Insects. Hémiptères. Librairie encyclopédique de Roret, Paris, xxxvi + 675 pp., 12 pls.

CAI W. 1995: Yangicoris, a new genus of Dicrotelini (Heteroptera: Reduviidae: Harpactorinae) from China. - Entomotaxonomia 17: 1-5.

CaI W. \& Tomokuni M. 2003: Camptibia obscura, gen. and sp. n. (Heteroptera: Reduviidae: Harpactorinae) from China. - Eur. J. Entomol. 100: 181-185.

CAI W. \& WANG Y. 1998: A review of Chinese Isyndus Stål (Heteroptera: Reduviidae: Harpactorinae). - Acta Entomol. Sin. 41: 163-179 [in Chinese, English abstr.].

ChInA W.E. 1940: Key to the subfamilies and genera of Chinese Reduviidae with descriptions of new genera and species. Lingnan Sci. J. 19: 205-255.

DAVIS N.T. 1969: Contribution to the morphology and phylogeny of the Reduvioidea. Part IV. The harpactoroid complex. Ann. Entomol. Soc. Am. 62: 74-94.

Distant W.L. 1903-1904: The Fauna of British India, Including Ceylon and Burma. Rhynchota 2 (Heteroptera). Taylor 
and Francis, London, 503 pp. [pp. 1-242: 1903; pp. 243-503: 1904].

Forero D. 2011: Classification of Harpactorinae assassin bugs (Hemiptera: Heteroptera: Reduviidae). - Bol. Mus. Entomol. Francisco Luis Gallego 3: 9-24.

Forero D. \& Weirauch C. 2017: Resin-enabled maternal care is an old evolutionary strategy in New World resin bugs (Hemiptera: Reduviidae). — Zool. J. Linn. Soc. 179: 62-91.

Forero D., Choe D.H. \& Weirauch C. 2011: Resin gathering in Neotropical resin bugs (Insecta: Hemiptera: Reduviidae) functional and comparative morphology. - J. Morphol. 272: 204-229.

Gil-Santana H.R. 2015: Parahiranetis salgadoi, a new genus and species of Harpactorini (Hemiptera: Heteroptera: Reduviidae), with a key to Neotropical wasp-mimicking harpactorine genera. - Acta Entomol. Mus. Nat. Prag. 55: 29-38.

Grundy P.R. 2007: Utilizing the assassin bug, Pristhesancus plagipennis (Hemiptera: Reduviidae), as a biological control agent within an integrated pest management programme for Helicoverpa spp. (Lepidoptera: Noctuidae) and Creontiades spp. (Hemiptera: Miridae) in cotton. - Bull. Entomol. Res. 97: 281-290

GustafsSON B. 2006: A Checklist of the Heteroptera in the Swedish Museum of Natural History. URL: http://www2.nrm.se/en/ het_nrm/heteroptera.html.

Hsiao T.-Y. 1979a: New species of Harpactorinae from China I (Hemiptera: Reduviidae). - Acta Zool. Sin. 4: 137-155 [in Chinese, English abstr.].

HsiaO T.-Y. 1979b: New species of Harpactorinae from China II (Hemiptera: Reduviidae). - Acta Zool. Sin. 4: 238-259 [in Chinese, English abstr.].

Hsiao T.-Y. \& Ren S.-Z. 1981: Reduviidae. In Hsiao T.-Y., Ren S.-Z., Zheng L.-Y., Jing X.-L., Zou H.-G. \& Liu S.-L. (eds): A Handbook for the Determination of the Chinese Hemiptera-Heteroptera (II). Science Press, Beijing, pp. 390-538 [in Chinese, English abstr.].

HoffmanN W.E. 1944: Catalogue of Reduviidae of China. Lingnan Univ. Sci. Bull. 10: 1-80.

HuA L.Z. 2000: XVIII. Order Hemiptera. In Hua L.Z. (ed.): List of Chinese Insects. Vol. 1. Zhongshan University Press, Guangzhou, pp. 162-216, 270-273 [in Chinese].

Maldonado Capriles J. 1990: Systematic Catalogue of the Reduviidae of the World (Insecta: Heteroptera). University of Puerto Rico (special edition of Caribbean Journal of Science), Mayagüez, $694 \mathrm{pp}$.

Miller N.C.E. 1941: New genera and species of Malaysian Reduviidae (contd.) Part II. - J. Fed. Malay St. Mus. 18: 601-773.

Miller N.C.E. 1971: The Biology of the Heteroptera (2nd rev. ed.). E.W. Classey, London, xiii + 206 pp., 5 pls.

Putshkov P.V. \& Putshkov V.G. 1996: Family Reduviidae Latreille, 1807, assassin bugs. In Aukema B. \& Rieger C. (eds) Catalogue of the Heteroptera of the Palaearctic Region, Vol. 2, Cimicomorpha I. The Netherlands Entomological Society, Amsterdam, pp. 148-265.

Schun R.T. \& Slater J.A. 1995: True Bugs of the World (Hemiptera: Heteroptera). Cornell University Press, Ithaca and London, $\mathrm{xii}+337 \mathrm{pp}$.

Schun R.T., Weirauch C. \& Wheeler W.C. 2009: Phylogenetic relationships within the Cimicomorpha (Hemiptera: Heteroptera): a total-evidence analysis. - Syst. Entomol. 34: 15-48.
Shorthouse D.P. 2010: SimpleMappr, an Online Tool to Produce Publication-quality Point Maps. URL: https://www.simplemappr.net (last accessed 7 Apr. 2020).

Tallamy D.W., Walsh E. \& Peck D.C. 2004: Revisiting paternal care in the assassin bug, Atopozelus pallens (Heteroptera: Reduviidae). - J. Insect Behav. 17: 431-436.

WeIRAUCH C. 2006: Observations on the sticky trap predator Zelus luridus Stål (Heteroptera: Reduviidae: Harpactorinae), with the description of a novel gland associated with the female genitalia. - Denisia 50: 1169-1180.

Weirauch C. 2008a: Cladistic analysis of Reduviidae (Heteroptera: Cimicomorpha) based on morphological characters. Syst. Entomol. 33: 229-274.

WeIRAuCh C. 2008b: From four- to three-segmented labium in Reduviidae (Hemiptera: Heteroptera). - Acta Entomol. Mus. Nat. Prag. 48: 331-344.

Weirauch C. \& Munro J.B. 2009: Molecular phylogeny of the assassin bugs (Hemiptera: Reduviidae), based on mitochondrial and nuclear ribosomal genes. - Mol. Phylogenet. Evol. 53: 287-299.

Weirauch C., Bérenger J.-M., Berniker L., Forero D., Forthman M., Frankenberg S., Freedman A., Gordon E., HoeyChamberlain R., Hwang W.S. et Al. 2014: An illustrated identification key to assassin bug subfamilies and tribes (Hemiptera: Reduviidae). - Can. J. Arthr. Identif. 26: 1-115.

Wu C.F. 1935: Catalogus Insectorum Sinensium, Vol. 2. Fan Memorial Institute of Biology, Peiping, vi +634 pp.

Zhang G. \& Weirauch C. 2013: Sticky predators: a comparative study of sticky glands in harpactorine assassin bugs (Insecta: Hemiptera: Reduviidae). — Acta Zool. 94: 1-10.

Zhang G. \& Weirauch C. 2014: Molecular phylogeny of Harpactorini (Insecta: Reduviidae): correlation of novel predation strategy with accelerated evolution of predatory leg morphology. - Cladistics 30: 339-351.

Zhang J., Weirauch C., Zhang G. \& Forero D. 2016: Molecular phylogeny of Harpactorinae and Bactrodinae uncovers complex evolution of sticky trap predation in assassin bugs (Heteroptera: Reduviidae). - Cladistics 32: 538-554.

ZhaO P., Yuan J. \& CAI W. 2006: Maldonadocoris annulipes, a new genus and new species of Harpactorinae (Heteroptera: Reduviidae: Harpactorinae) from China. - Zootaxa 1169: 61-68.

ZhaO P., CAI W. \& REN D. 2007: Liangcoris, a new genus of Harpactorinae (Hemiptera: Reduviidae) from China. - Zootaxa 1405: 63-68.

Zhaо P., Luo Z. \& CAI W. 2009: Iocoris nodulifemoralis, a new genus and new species of Harpactorinae (Hemiptera: Heteroptera: Reduviidae) from China. - Zootaxa 2129: 63-68.

Zhao P., Pham M., Truong X.L. \& Cai W. 2014: Flexitibia, a new genus of Harpactorinae (Hemiptera: Heteroptera: Reduviidae), with a discussion on the functional morphology of fore legs of the related genera. - Zootaxa 3795: 564-570.

Zhao P., Ren S., Wang B. \& Cai W. 2015: Cosmosycanus perelegans (Hemiptera: Reduviidae: Harpactorinae), a new record from China, with report of its female genitalia. - Zootaxa 3936: $567-574$.

Received February 14, 2020; revised and accepted May 5, 2020 Published online May 26, 2020 